\title{
Development of Learning Media Based on Realistic Mathematics Learning Approach Assisted by Macromedia Flash to Improve Students' Mathematical Reasoning Ability at MTs Negeri 1 Langsa
}

\author{
Nadyaturrahmi Edi Syahputra Elmanani Simamora \\ Mathematics Education, Postgraduate School, State University of Medan \\ Medan, North Sumatra, Indonesia
}

\begin{abstract}
This research aims to: (1) To determine the validity, effectiveness, and practicality of learning media assisted by Macromedia flash; (2) To analyze whether the learning media assisted by Macromedia Flash based on the RME approach is able to improve the mathematical reasoning abilities of class VIII students at MTs Negeri 1 Langsa. This research includes development research. This research uses Thiagarajan 4-D development model. This research was carried out at MTs Negeri 1 Langsa in the even semester of the 2020/2021 academic year. The subjects in this study were students of class VIII-2 MTs Negeri 1 Langsa. The results of this study indicate that: (1) the developed learning media has met the criteria of being valid, practical, and effective; (2) Increasing students' mathematical reasoning abilities using learning media developed on cube and block material, the average value increased from trial I of 69,5 to 77,08 in trial II.
\end{abstract}

Keywords:Pendekatan Pembelajaran Matematika Realistik, Macromedia Flash, kemampuan Penalaran Matematis

DOI: $10.7176 / \mathrm{JEP} / 13-3-03$

Publication date: January $31^{\text {st }} 2022$

\section{INTRODUCTION}

One of the characteristics of the progress of a nation can be seen from the progress in the field of Science and Technology (IPTEK). According to the National Research Council (NRC), people must be familiar with the basic concepts of science, mathematics, engineering, and technology in order to think critically about the world and make intelligent decisions on personal and societal issues. From this we can see that mathematics has an important role in developing science, resources and advances in science and technology. Sujono [1] regarding the role of mathematics, he said about the development of mathematics in the modern era very rapidly because with the help of mathematics all sciences become more perfect. Mathematics is an efficient tool that is needed by all sciences so that without the help of mathematics all will not get any meaningful progress.

According to Hasratuddin [2], the vision of mathematics education today is mastery of concepts in mathematics learning that are used to solve problems. Meanwhile, the vision of future mathematics education is to provide opportunities to develop a mindset, self-confidence, beauty, objective and open attitude.

The material from mathematics is abstract, this makes the mathematics material not easily understood by most students, plus the current view of students towards mathematics is not good. Therefore, learning media is needed to help students understand the concept of learning and apply mathematics to everyday life. Teachers are not only required to master science, but also must have the skills to choose and use and cultivate (create or develop) the media well [3].

The results of BAVA (British Audio Visual Aids) research explain that learning outcomes that do not use media are only absorbed by $13 \%$ of the total material that has been given. By using learning media the acquisition of absorbed teaching materials can be increased up to $86 \%$. The importance of using media is also expressed by Rusman [3] stating that in the learning process, the media plays an important role in achieving learning objectives. This is confirmed by Arsyad's opinion [4] which states that the use of learning media at the learning orientation stage will greatly help the effectiveness of the learning process and delivery of the learning message.

Muhtaron [5] in his research on the effect of using Compact Disc of Math (CD-M) as a medium for learning mathematics on student learning outcomes also concluded that the learning outcomes of students who were taught by media were higher than those who were not taught by media.

In addition, the problem that occurs today is that students have not been able to reason about the questions given. This is because students are only fixated on numbers, so that if a mathematical problem is presented in the form of a problem in the form of a symbol or in-depth analysis, the student will not be able to solve it.

Responding to the problems that arise in learning mathematics above which result in the low ability of students' mathematical reasoning in learning mathematics, it is necessary for teachers and researchers to choose learning that can overcome these problems. One approach that can help students improve their reasoning in learning mathematics is the Realistic Mathematics Approach, which confronts students with real problems related 
to everyday life so that students are able to be actively involved in learning and provide opportunities for students to rediscover mathematical concepts. through the guidance of the teacher (guide reinvention). The guidance is given through a series of questions or by providing student activity sheets. Thus, this Realistic Mathematics Approach can overcome students' difficulties in the learning process to improve mathematical reasoning abilities in the flat-sided geometry material at MTs Negeri 1 Langsa.

According to Tandililing [6], the concept of Realistic Mathematics is in line with the need to improve mathematics education in Indonesia in terms of overcoming the problem of how to increase students' understanding of mathematics, so that they can develop their reasoning power. With such learning in the end can generate enthusiasm, the ability to explore, thinking exploration skills and independence in solving problems. The mathematical software used in this study is Macromedia Flash which is very suitable for use in designing images, animations, graphics, videos and others so that teachers can design interesting and innovative learning so that it can make it easier for students to improve their mathematical reasoning abilities.

The characteristics of students are also one of the reasons for the need to develop learning media because they often do not match the learning media with the student's situation and condition. For example ownership of ICT, ICT expertise, social environment, culture, student abilities, interest in learning and family background. Therefore, the development of learning media must be adapted to the characteristics of students as targets.

Based on the results of interviews that the researchers conducted with 5 mathematics teachers at MTs Negeri 1 Langsa about the importance of developing learning media, they said that they needed interactive learning media in learning on the grounds that the learning process became more interesting, students were more active and the learning process became more effective.

Based on the analysis of these needs, effective learning media are in accordance with development needs. In addition, MTs Negeri 1 Langsa also has facilities and infrastructure that are in accordance with development needs such as: computer laboratory room, internet network with wifi facilities, LCD projectors, but teachers have not been able to optimally empower these facilities and infrastructure. This encourages researchers to develop learning media for mathematics class VIII on the subject of cubes and blocks using technology-assisted software Macromedia Flash.

\section{METHOD}

\section{Research Pattern}

This research includes development research. This study uses a 4-D Thiagarajan development model and the product in this research is learning media assisted by Macromedia Flash with the material Build flat side space (Cube and Block).

\section{Subject}

The subjects in this study were students of class VIII-2 of MTs Negeri 1 Langsa on the grounds that the school distributed all students of class VIII-2 randomly.

\section{Instruments}

To assess the learning media that have been developed, in this development research, the following data collection instruments were used:

a) Questionnaire Sheet

Questionnaire sheets used in this research are questionnaire sheets for subject matter experts, questionnaire sheets for learning media experts, practicality questionnaire sheets for learning media for mathematics teachers and students, and questionnaire sheets for student learning independence.

b) Mathematical Reasoning Ability Test

The data of this study were analyzed quantitatively. The purpose of this research method is to find out the difference in the increase in mathematical reasoning of high school students as a result of learning. The two classes that will be conducted in this research are located at MTs Negeri 1 Langsa class VIII-3 and at MTs Private Ulumul Quran Langsa class VIII-2.

Table 1. Mathematical Reasoning Ability Test Grid

\begin{tabular}{|l|l|l|}
\hline \multicolumn{1}{|c|}{ Aspect } & \multicolumn{1}{|c|}{ Measured indicators } & Question Number \\
\hline $\begin{array}{l}\text { Mathematical } \\
\text { Reasoning }\end{array}$ & $\begin{array}{l}\text { Presenting mathematical statements orally, in writing, pictures, and } \\
\text { diagrams. }\end{array}$ & 1 \\
\cline { 2 - 3 } & $\begin{array}{l}\text { Drawing conclusions, compiling evidence, providing reasons or evidence } \\
\text { for some solutions. }\end{array}$ & 2 \\
\cline { 2 - 3 } & Submit a conjecture & 3 \\
\cline { 2 - 3 } & Perform mathematical manipulation & 4 \\
\hline
\end{tabular}




\section{Learning Media Development Procedure}

In the development of mathematics learning media assisted by Macromedia Flash, the 4-D (Four-D) development model is used. according to Thiagarajan [7], the 4D research and development model consists of 4 main stages, namely define, design, develop, and disseminate. According to Trianto [8] the 4D development model can be adapted into 4Ps, namely definition, design, development, and deployment. The application of the main steps in the study is not only based on the original version but is adjusted to the characteristics of the subject and the examinee's place of origin.

\section{a) Define Stage (Defining)}

The purpose of this stage is to define and define the learning conditions. In determining and setting learning conditions, it begins with an analysis of the objectives of the material limitations developed in the learning media.

b) Design Phase (Design)

The design stage aims to design learning media. There are four steps that must be taken at this stage, namely: (1) Making a storyboard which includes making a sketch or screen image in the form of pages and frames, then choosing colors, types of writing, storyline and also selecting the appropriate animation. (2) The arrangement of the material in the learning media which includes the layout that will be used, (3) the making of learning scenarios which include the order of the material to be delivered (4) Making LKS which refers to the learning material which is visualized with the use of assisted learning media Macromedia Flash.

c) Development Stage (Develop)

The purpose of the development stage is to produce a good final learning media. In the first draft, the media and research instruments were validated by experts, then the test instrument for students' mathematical reasoning abilities was tested in classes outside the sample. Then a field trial was carried out, which aimed to obtain direct input to the teaching materials that had been prepared so as to produce the final media.

d) Stage of Dissemination (Disseminate)

The development of learning media reaches the final stage if a positive assessment has been obtained from experts and through development tests. Learning media are then packaged, distributed, and set for a wider scale. The learning media based on the realistic mathematics approach in this study was distributed in a limited way only to class VIII MTs Negeri 1 Langsa with 15 students. At this stage, the effectiveness of the learning media which has been effective at the development stage is re-examined (draft III). This is to see if other classes using these learning media are still effective by being tested on students with more diverse abilities.

\section{RESULTS AND DISCUSSION}

The Validity of the Development of Macromedia Flash-Assisted Mathematics Learning Media

Analysis of the validity of the mathematics learning media assisted by Macromedia Flash that was developed was seen from two aspects of the assessment:

a) Assessment of learning media experts/practitioners

b) Assessment of experts/practitioners of mathematics learning materials

At the development stage, the assessment of the experts/practitioners has been explained previously, where the results of the assessment are declared valid media. For more details, see the table.

Table 2. Results of Learning Media Validation by Experts

\begin{tabular}{|l|c|c|}
\hline \multicolumn{1}{|c|}{ Validator } & Average Score & Criteria \\
\hline Mathematics Learning Media Expert & 4,53 & Valid \\
\hline Mathematics Learning Material Expert & 4,52 & Valid \\
\hline
\end{tabular}

\section{Practicality of Macromedia Flash-Based Learning Media Development}

The developed learning media is said to be practical in terms of the assessment of experts/practitioners. The developed learning media is stated to be able to be used with little or no revision and in terms of the results of the questionnaire on the practicality of the mathematics learning media distributed to students at school.

This questionnaire was filled out by students who took part in learning mathematics using learning media assisted by Macromedia Flash which was developed as many as 10 questionnaire items arranged according to the practicality questionnaire grid for learning media.

The macromedia flash-assisted mathematics learning media developed in this study is said to be practical if the scores obtained from the practicality test questionnaire filled out by students have a practicality score of at least $76 \%$ in the practical category. The results of the practicality of learning media questionnaire scores are presented in Table 3. : 
Table 3. Average Score of the Practicality Questionnaire of Mathematics

Learning Media Trial I

\begin{tabular}{|l|c|l|}
\hline Aspects Observed & Practicality Score (\%) & Practical Criteria \\
\hline Effective aspect & 85,5 & Practical \\
\hline Interactive aspect & 84,5 & Practical \\
\hline Interesting aspect & 90 & Very Practical \\
\hline Efficient aspect & 81,6 & Practical \\
\hline creative aspect & 77 & Practical \\
\hline
\end{tabular}

Table 3. shows that the average score of the practicality questionnaire of the macromedia flash-assisted mathematics learning media developed is in the practical and very practical category with a score for the effective aspect of $85.5 \%$, the interactive aspect of $84.5 \%$, the interesting aspect of $90 . \%$, the efficient aspect is $81.6 \%$ and the creative aspect is $77 \%$. Based on the criteria for the practicality of the learning media described earlier in Chapter III, it can be concluded that the mathematics learning media developed is quite practical. The results of the questionnaire practicality of learning media in the second trial are presented in Table 4.:

Table 4. Average Score of the Practicality Questionnaire of Mathematics

Learning Media Trial II

\begin{tabular}{|l|c|l|}
\hline $\begin{array}{l}\text { Aspects } \\
\text { Observed }\end{array}$ & $\begin{array}{c}\text { Practicality } \\
\text { Score (\%) }\end{array}$ & $\begin{array}{l}\text { Practical } \\
\text { Criteria }\end{array}$ \\
\hline Effective aspect & 82,98 & Practical \\
\hline Interactive aspect & 80,21 & Practical \\
\hline Interesting aspect & 82,72 & Practical \\
\hline Efficient aspect & 78,70 & Practical \\
\hline creative aspect & 77,91 & Practical \\
\hline
\end{tabular}

Table 4. shows that the average score of the practicality questionnaire of the macromedia flash-assisted learning media developed is in the practical category with a score for the effective aspect of $82.98 \%$, the interactive aspect of $80.21 \%$, and the interesting aspect of $82.72 \%$, the efficient aspect is $78.70 \%$ and the creative aspect is $77.91 \%$

Based on the criteria for the practicality of the learning media described earlier in Chapter III, it can be concluded that the mathematics learning media developed is quite practical.

\section{The Effectiveness of Macromedia Flash-Based Mathematics Learning Media Development}

Description of the effectiveness of learning media assisted by Macromedia Flash is said to be effective if the level of students' mathematical reasoning abilities is at least $85 \%$ of the total number of students or a minimum score of 2.67 after being converted to a standard value of 4 .

The level of mastery of students' mathematical reasoning abilities on the results of the first trial test can be seen in table 5 .

Table 5. Classification of Mastery of Mathematical Reasoning Ability Test Results Test I

\begin{tabular}{|c|c|c|c|l|}
\hline Number & Interval Value & $\begin{array}{c}\text { The } \\
\text { number of } \\
\text { students }\end{array}$ & $\mathbf{\%}$ & Category \\
\hline 1 & $0 \leq \mathrm{VRA}<54$ & 0 & $0 \%$ & Very low \\
\hline 2 & $54 \leq \mathrm{VRA}<65$ & 6 & $40 \%$ & Low \\
\hline 3 & $65 \leq \mathrm{VRA}<79$ & 6 & $40 \%$ & Currently \\
\hline 4 & $79 \leq \mathrm{VRA}<89$ & 3 & $20 \%$ & Tall \\
\hline 5 & $89 \leq \mathrm{VRA} \leq 100$ & 0 & $0 \%$ & Very high \\
\hline
\end{tabular}

Description : VRA adalah Value of Reasoning Ability

Table 5. shows that there are 6 students who scored in the low category (40\%), 6 students who scored in the medium category (40\%) and 3 students scored in the high category $(20 \%)$ while for the score in the very high category. and very low, none of the students got it $(0 \%)$.

The results of classical completeness of students' mathematical reasoning abilities in the first try can be seen in the following table: 


Table 6. Classical Completeness Level of Mathematical
Reasoning Ability of Trial Students I
\begin{tabular}{|l|c|c|}
\hline \multirow{2}{*}{ Category } & Students' Mathematical Reasoning Ability \\
\cline { 2 - 3 } & The number of students & Percentage \\
\hline Complete & 9 & $60 \%$ \\
\hline Not Complete & 6 & $40 \%$ \\
\hline Amount & 15 & $100 \%$ \\
\hline
\end{tabular}

Based on Table 6. above, it can be seen that classical student learning completeness from the results of the mathematical reasoning ability test is that 9 students out of 15 students complete or only $60 \%$ of students complete classically. In accordance with the criteria for classical student learning completeness, at least $85 \%$ of students who take the mathematical reasoning ability test are able to achieve a minimum score of B-. So the test results of students' mathematical reasoning abilities have not been completed classically, because only $60 \%$ of students are able to achieve a B- score. So it can be concluded that in the first trial the application of learning media assisted by macromedia flash that was developed did not meet the criteria for achieving mastery classically.

The level of mastery of students' mathematical reasoning abilities on the results of the second trial test can be seen in table 7. :

Table 7. Classification of Mastery of Mathematical Reasoning Ability Test Results Trial II

\begin{tabular}{|c|c|c|c|l|}
\hline Number & Interval Value & The number of students & $\mathbf{\%}$ & Category \\
\hline 1 & $0 \leq \mathrm{VRA}<54$ & 0 & $0 \%$ & Very low \\
\hline 2 & $54 \leq \mathrm{VRA}<65$ & 2 & $13 \%$ & Low \\
\hline 3 & $65 \leq \mathrm{VRA}<79$ & 8 & $53 \%$ & Currently \\
\hline 4 & $79 \leq \mathrm{VRA}<89$ & 5 & $34 \%$ & Tall \\
\hline 5 & $89 \leq \mathrm{VRA}<100$ & 0 & $0 \%$ & Very high \\
\hline
\end{tabular}

Description : VRA adalah Value of Reasoning Ability

Table 7. shows that there are 2 students who scored in the low category (13\%), while for the very high and very low categories, none of the students got it $(0 \%)$. For the medium category there were 8 students who got it $(53 \%)$, and for the high category there were 5 students who got it $(34 \%)$. The level of mathematical reasoning ability of the students from the test II test results that most dominate is the score in the medium category as many as 8 people, 5 people in the high category then followed by the low category as many as 2 people. From 15 students in class VIII-2, it can be seen that there was an increase in the students' mathematical reasoning ability in the second trial.

The results of classical completeness of students' mathematical reasoning abilities in the second trial can be seen in the following table:

\begin{tabular}{|l|c|c|}
$\begin{array}{c}\text { Table 8. Classical Completeness Level of Mathematical } \\
\text { Reasoning Ability of Trial II Students }\end{array}$ \\
\hline \multirow{2}{*}{ Category } & Students' Mathematical Reasoning Ability \\
\cline { 2 - 3 } & The number of students & Percentage \\
\hline Complete & 13 & $87 \%$ \\
\hline Not Complete & 2 & $13 \%$ \\
\hline Amount & 15 & $100 \%$ \\
\hline
\end{tabular}

Table 8. shows that students' learning mastery classically from the results of students' mathematical reasoning ability tests, namely students who completed were 13 students out of 15 students or about $87 \%$ of students whose scores were classically complete. In accordance with the criteria for classical student learning completeness, at least $85 \%$ of students who take the mathematical reasoning ability test are able to achieve a minimum score of B-. Then the results of the students' mathematical reasoning ability test have been completed classically, because there are $87 \%$ of students who are able to achieve a minimum score of B-. So it can be concluded that in the second trial the application of learning media assisted by macromedia flash that was developed already met the criteria for achieving mastery classically.

\section{CONCLUSION}

1. The validity of the developed mathematics learning media is included in the valid category in terms of the validity value of the learning media with an average total media validity of 4.53 from media experts and 4.52 from subject matter experts, then the total validity of lesson plans is 4.54 , LAS is 4.5 and so is the mathematical reasoning ability test is declared valid.

2. The developed mathematics learning media has also met the practical criteria in terms of media validity by experts who stated that the media was valid with little or no revision and also in terms of the media practicality 
test questionnaire in trials I and II which stated that the mathematics learning media developed is classified in the practical category with a practicality test value of $76 \%$.

\section{ACKNOWLED}

The developed mathematics learning media meets the effective criteria, namely in terms of classical student learning completeness has reached $87 \%$ in the second trial. Increasing students' mathematical reasoning abilities using learning media developed on cube and block material, the average value increased from the first trial of 69.5 to 77.08 in the second trial. Furthermore, the average student response score was $94 \%$ in the "positive" category in the first trial and $97 \%$ in the "positive" category in the second trial. The average achievement of learning time using Macromedia Flash is the same as the usual time of achievement, so the learning media can be said to be effective.

The authors thank the anonymous reviewers for their helpful suggestions and comments on the previous versions of this article.

\section{REFERENCES}

[1] Sujono, (1988). Pengajaran Matematika Untuk Sekolah Menengah. Jakarta: Department Pendidikan dan Kebudayaan Direktorat Jendral Pendidikan Tinggi Proyek Pengembangan Lembaga Pendidikan Tenaga Kependidikan.

[2] Hasratuddin. 2015. Mengapa Harus Belajar Matematika. Perdana Publishing: Medan.

[3] Rusman. (2013). Seri Manajemen Sekolah Bermutu Model-Model Pembelajaran Mengembangkan Profesionalisme Guru, Jakarta: Raja Grafindo Persada.

[4] Arsyad, A. 2015. Media Pembelajaran. Jakarta: Raja Grafindo Persada.

[5] Muhtaron. (2010), Pengaruh Pennggunaan Compact Disc of Math (CD-M) Sebagai Media Pembelajaran Matematika Terhadap Hasil Belajar Siswa Kelas X SMA Negeri 2 Mraggen, Jurnal Aksioma, (Online), Vol.1, No.1/ Maret 2010, ISSN:2086-2725

[6] Tandiling, E. (2010). Imlementasi Realistic Education (RME) di Sekolah. Jurnal Untan (Online). Vol 25 (3), 1-9.

[7] Thiagarajan, S.; Semmel, D.S \& S emmel, M.I. 1974. Instructional Development For Training Teachersof Exceptional Children, Indiana : Indiana University Blomington

[8] Trianto. (2013). Mendesain Model Pembelajaran Inovatif-Progresif: Konsep, Landasan dan Implementasinya pada Kurikulum Tingkat Satuan Pendidikan (KTSP), Jakarta: Kencana Prenada Media Grup. 